\title{
WACIKA FOR OPTIMIZING THE BALANCED UTILITY OF STRATEGIC MANAGEMENT ACCOUNTING
}

\author{
Made Susilawati ${ }^{1^{*}}$, Unti Ludigdo ${ }^{2}$, Gugus Irianto ${ }^{2}$, and Zaki Baridwan ${ }^{2}$ \\ ${ }^{1}$ Student of Doctoral Program in Accounting, Universitas Brawijaya, Indonesia \\ ${ }^{2}$ Accounting Department, Faculty of Economics and Business, Universitas Brawijaya, \\ Indonesia
}

\begin{abstract}
This study aims to examine wacika, the words of wisdom based on dharma, i.e. truth and virtues, used as a conceptual framework for Strategic Management Accounting (SMA). This postmodern qualitative research uses wacika as its instrument of analysis, focusing on guidelines for SMA according to local content. The analysis was conducted by comparing wacika values with the field data filtered through reflections. The results indicate that there are six wacika concepts found in the wacika-based SMA conceptual framework, which has three levels. The first level, the tattwa, is objectives, which contains one concept. The second level, the susila, contains two concepts of assumptions and two concepts of principles. The third level, the upacara, is the characteristics of information, containing one concept. This wacika-based framework provides a basis for practitioners to provide, communicate, and literate useful information to the management and provide both material and non-material benefits and positive energy.
\end{abstract}

Keywords: management decisions, comparative analysis, reflection, cooperative, conceptual framework

\section{INTRODUCTION}

Some people in Indonesia still believe that cooperatives are not promising forms of business in terms of increasing prosperity. Moreover, cooperatives in general have a negative stigma, which may be caused by the management's behavior in managing them (Setiawaty, 2012). The problems of management in small and medium enterprises are caused by poor management accounting practices (Aziz, 2012). Furthermore, management accounting basically helps overcome the sluggishness of organization (Nyamori, 2000). It indicates that management accounting has not contributed significantly to performance of cooperatives (Shank, 2006). The usefulness of management accounting practices needs to implemented in the management process of small and medium enterprises (Ahmad, 2012) such as cooperatives. This indicates that management accounting has a significant role in the planning, organizing, controlling, and the decision-making process conducted by cooperatives' management and that it influences the optimal performance of the cooperatives. Practitioners of management accounting need a reference in carrying out their roles and functions in 
accordance with local content, which is common interest. Therefore, it is necessary to conduct studies to build a conceptual framework for management accounting in Hindu cooperatives to be used as a reference for management accounting practitioners to accommodate the need for management accounting development that provides material and non-material benefits. This view is formed since some cooperatives have not been able to prove their performance to the public. In fact, there are some cooperatives that embezzle their members' funds, go bankrupt, or are dissolved due to mismanagement. This condition is inseparable from failure in managing information, which is actually required by the management for decision making. The information in question is management accounting information.

Some cooperatives oversimplify information as a monotonous routine, which is slow and difficult to develop. Many cooperative members and supervisors do not have sufficient information and do not make proper communication resulting in knowledge gaps that lead to poor management and decision making. The condition makes the management left uncontrolled, potentially leading to moral hazards. The hazards can be reduced by implementing religious values since they are considered capable of overcoming morals hazards through the influential relationship between religion and behavior (Mathras, Cohen, Mandel, \& Mick, 2015). Thus, management accounting needs to adapt local content to minimize moral hazard and to stimulate useful management accounting.

Management accountants are insisted to "work harder" to solve operational and tactical problems (Šoljaková, 2012). This suggests that accounting needs to be evaluated since its contributions to social welfare remain in question (Sudaryanti, Sukoharsono, Baridwan, \& Mulawarman, 2015). This is supported by the opinion that social characteristics contribute to the way management accounting practices play a more positive role in management (Seal, 2006). This results in the negligence of accountants or question whether practitioners should be involved in the management's decision making. In fact, management accounting is criticized for losing its relevance to management and other users of information (Forsaith, Tilt, \& Xydias-lobo, 2004; Ho, 2014). In this regard, the function and role of management accounting will be perceived as important when it is oriented more strategically (Lord, 1996; Ma \& Tayles, 2009; R. Roslender, S. Hart, 1998; Ramljak, 2012). Therefore, management accountants should have the expertise to develop a strategic information bank as well as to formulate and communicate a strategy map (Dixon, 1998; Roslender \& Hart, 2010).

Based on the foregoing discussion, the present study deals with strategic management accounting (SMA) since it is more strategy-oriented than technical. The view is supported by Belkaoui (2002) stating that management accounting remains lacking of strategic relevance. The strategic dimension view positions management accounting into SMA (Belkaoui, 2002; Brouthers \& Roozen, 1999; Fowzia, 2011; Juras, 2014; Nyamori, 2000; Shank, 2006). This indicates that SMA basically has the same root as management accounting. In addition, it also shows that SMA needs to restructure the active role of accounting in management and strategic decision making processes (Belkaoui, 2002). Thus, SMA provides strategic information needed by management on performance evaluation, risk, and strategy recommendations for work system improvement and business development. 
Ironically, cooperatives put more emphasis on the material than the spiritual values (Sudaryanti et al., 2015). Cooperative's orientation that pursues mere material well-being contradicts the Bhagawad Gita (II.48). Bhagawad Gita mentions that human's duty shall be done in a balanced way, in terms of both sekala and niskala. In this paper, the local content is Hinduism, which was wacika, implemented in SMA. Wacika is holy words of wisdom oriented to relevance to dharma. Wacika was used since the research objects are cooperatives that implement Hinduism. Thus, SMA needs to bridge the interest of business to dharma. Both interests are the interests of cooperatives' members as well as the management. This is due to the fact that Hindu cooperatives are business entities established based on the common interests of individual communities. This community carries with them inherent values formed through internalization of wacika in carrying out their life activities, including SMA. Thus, the business, by means of mutual help, will be useful in achieving common goals that take the balance between material and non-material welfare into account. The efforts to achieve a balanced material and non-material welfare require a shared commitment. This commitment requires proactivity of the cooperative's stakeholders (Hoque, 2006). The commitment to accommodate common interests occurs in cooperatives because the owners and the management are derived from the members. It means that individual values form the community, and individuals are formed by the community values of the cooperative. It builds togetherness in dharma-oriented cooperatives. This togetherness forms the soul of cooperative, which is self-helping and self-activating, that drives toward mutual prosperity. The cooperative refers to the efforts from, for, and by the members aimed at achieving the welfare of its members in sekala (material) and niskala (non-material) aspects. This shows that cooperatives are formed by shared consciousness.

R. Roslender, S. Hart, 1998; Roslender \& Hart (2010) mentioned that management accounting function is generally carried out by senior managers. However, other professional groups also have management accounting capability (R. Roslender, S. Hart, 1998). This represents a criticism and challenge against the insignificant contributions of management accountant. In reality, cooperatives still have a small number of management accountants. The functions of management accountants are implemented more by supervisor or manager, so they are called as SMA practitioners.

This situation encourages SMA practitioners to optimize their capability to produce strategic-oriented information that management needs to maintain the health of the cooperative. Therefore, SMA practitioners need to support the formulation of business strategies and competitive advantage (R. Roslender, S. Hart, 1998). It indicates that management accountants are required not only to provide information (Hoffjan \& Wompener, 2006) but also to be able to communicate strategies derived from analytical results that cooperative management can use. Thus, SMA practitioners must be able to produce the required information (Lord, 1996) that can significantly contribute more accurate, precise, and fast information (Apak, Erol, Elagöz, \& Atmaca, 2012).

SMA will be able to reposition its role and function when it has a framework of values that serves as a reference for its practices (Belkaoui, 2002) that pay attention to the material and non-material welfare. Thus, a strategic accountant should have an indepth insight into business and functional relationships in a broader perspective (Shank, 2006). This is because management requires specialist advice from SMA practitioners 
regarding strategic and operational decisions (Coad, 1999). Thus, SMA practitioners are required to play a "livelier" role as an accountant who performs their strategic role needed by management. The concept of SMA is developed into strategic information needs formed from an interdisciplinary perspective aimed at building a sustainable competitiveness (Dunkovic, Juric, \& Nikolic, 2010; Noordin, Zainuddin, \& Tayles, 2009) in accordance with the needs of the organization from the SMA's perspective (LangfieldSmith, 2008; Noordin et al., 2009; Roslender \& Hart, 2010).

These practitioners' demands need to be bridged with a conceptual framework as a reference for generating valuable information. In addition, SMA studies requires SMA with the uniqueness of its strategic process in accordance with the entity (Ma \& Tayles, 2009). Thus, it needs a substantive and useful solution to address the root of the problem. It means that SMA needs to adapt to substantive local content.

SMA serves as an action trigger that delivers values and positive impact to management decision-making. The SMA referring to wacika is one of three elements of Tri Kaya Parisudha (TKP). TKP means behavior according Hinduism that consists of kind thinking, kind words, and kind deeds which distribute the vibration dharma (wisdom/kindness). TKP is the three foundations of ethical teachings of Hinduism that act as self-control in daily life based on dharma (Sarasamuscaya, sloka 72). TKP consists of good thinking based on dharma (manacika), good words based on dharma (wacika), and good deeds based on dharma (kayika) (Sarasamuscaya, sloka 75). The other elements of TKP are studied in other research articles.

\section{THEORETICAL FRAMEWORK}

The energy of religious teachings plays a central role in the activities linking the synergy of goals addressing "what it should be" (Engineer, 2009). It harmonizes SMA in the balance of life so that SMA becomes a value driver through a reference framework of SMA. To achieve it, SMA uses the balance between the purpose of life and the purpose of SMA as self-control. It is because individuals and communities, including SMA practitioners, are inseparable from the obligation to carry out activities that refer to the purpose of life in Hinduism. The balance of purpose is implemented through TKP. Based on the foregoing, the conceptual framework of SMA should synergize the objectives of SMA and objectives of life in a balanced manner between material and non-material aspects according to dharma. Cooperatives being studied internalize wacika as culture.

Accounting is basically inseparable from its forming culture (Moll et al. in Hoque, 2006; Orsi, 2003; Zaitul, 1988) to be accepted by the public in its social norms. SMA in local entities is affected by traditional communities with its strong religious teachings (non-economic) and rationality (economic) (Alleyne, Marshall, 2011; Nishimura, 2005; Waweru, 2010). Thus, SMA needs to adapt to culture that has its own characteristics (Alleyne, Marshall, 2011) adjusted to the need of the cooperative. This means that SMA in cooperatives needs to adapt to religious teachings, culture, and environment so as to be capable of internalizing religious values into their activities. In this case, SMA should dynamically improve the role of its profession through internalization of local content that delivers religious values. Hinduism encourages activities to be guided by the purpose of life, which maintains the balance of life from the worldly (material) and 
heavenly (non-material) aspects. These religious values are capable of distributing the values that serve as the reference principles and behavior control (Mathras et al., 2015).

It is due to the fact that SMA is required to be a producer and deliverer of knowledge (McKinlay \& Pezet, 2010) and values (Kozarkiewicz \& Lada, 2014). Knowledge and values are actually the effort to achieve the ultimate goal of happiness (Sarasamuscaya, sloka 34). SMA practitioners have a task to develop ideas for optimizing cooperative's resources (Pipan \& Czarniawska, 2010). It means that SMA requires practitioners who are capable of developing communication network and building cooperation and can provide relevant information in strategic decision-making (Coad, 1996, 1999; Lo, 2011). In fact, SMA becomes the operation control center for cooperatives with strategic thinking expertise (Nyamori, 2000) supported by effective and innovative thinking in managerial decision-making (Nielsen, Mitchell, \& Nørreklit, 2014).

In this regard, the purpose of the present study is to build a framework of wacikabased SMA through the balance of material and non-material benefits based on dharma. The balance of benefits is an attempt to achieve the purpose of life according to Hinduism. The purpose of life is integrated in SMA. In this study, the purpose underlies the development of key coherent concepts of a conceptual framework (Belkaoui, 2006; Kieso, Weygandt, \& Warfield, 2011). Religion-based determination of purpose was used in order to be accepted by common interests and to avoid materialism and individualism. The unique nature of cooperatives is the only form of business where the owners, the management, the customers, and the employees are their own members. This uniqueness illustrates that the elements of cooperatives have common interests. Therefore, they are required to keep its synergistic goals commitment according to wacika in SMA.

\section{METHOD}

Community's demands on the benefits of SMA need to be followed up by enriching the value of SMA benefits. Baudrillard, a postmodern philosopher, encourages creative ideas that prioritize the nature of knowledge against knowledge that is considered established. In this study SMA is strengthened by a conceptual framework so that SMA practitioners have a reference in providing strategic information needed by management. In addition, this conceptual framework can develop SMA in theory.

Based on the foregoing, the present study is needed due to the importance of the role and function of SMA and a value framework of SMA as a basis to unify interests (Belkaoui, 2006). This conceptual framework is based on wacika since it aims at keeping the information generated through the use of life balance. This is due to fact that the accounting conceptual framework has not yet internalized the value of life and is only secular-oriented (Molisa, 2011). This conceptual framework is a substantive theory since it incorporates the values of wacika contextually. Strauss \& Corbin argued that substantive theory is a study in a particular substantive matter in the conceptual and theoretical level that encourages new ideas to develop a theory (Adler \& Adler in Denzin \& Lincoln, 2009). This substantive theory is formed from the internalization of wacika values in SMA applied in social practices. Social practices form a concept, and a concept constitutes parts of a theory since important concepts are used in practice, so a concept 
is a theory of practice (Llewelyn, 2003). This theory represents a new idea that is substantive since there is no theory that accommodate it.

A theory is a value statement (Adler \& Adler in Denzin \& Lincoln, 2009). However, the existing value statements remain limited to material values, so that it has not accommodated the non-material values. The balance of material and non-material values makes it closer to the ultimate meaning of life, which is to achieve the purpose of life according to dharma through wacika in SMA. Therefore, frameworks are used to interpret the ultimate meaning (Adler \& Adler in Denzin \& Lincoln, 2009). According to Hinduism the ultimate meaning of SMA is implemented through wacika. Wacika in SMA consists of information, communication and literacy which refers to dharma. This study examines SMA's conceptual framework, which is formed through conceptualization process.

The SMA conceptual framework needs to be supported by wacika as a positive energy driver. This is based on the view that SMA needs to be formed from the foundations of behavior ethics supported by the understanding of purposes, motivations, and decision-making models (Belkaoui, 2002). SMA has to accord its purpose as a control system and a trigger to improve performance (Al-Mawali \& Amoush, 2013; Shank, 2006). It is because decision-making is limited by values, the purpose-conception synergy, the level of knowledge, and information (Belkaoui, 2002). Thus, SMA has to be implemented in synergy of purposes to reach a material and nonmaterial balance. The synergy between business purposes and dharma purposes through the conceptual framework of wacika-based SMA represents a new perspective in SMA. A new perspective has a great strength in the development of a theory (Llewelyn, 2003). It took the form of a conceptual framework.

This conceptual framework is formed from the synergy of relationships between concepts, which are formed through a process of conceptualization. This process is done by comparing data from different sources. The purpose of this comparison is to avoid bias and errors, to achieve accuracy and consistency, and to ensure that the concepts are in the right classification (Corbin \& Strauss, 1990). Furthermore, the concept of theorizing need to be supported by researcher's reflection in giving the meaning of practical experience to develop a theory (Llewelyn, 2003). Therefore, the method of analysis used in this study is wacika analysis, which is a combination of comparative analysis and reflection. The researcher kept making the analysis by referring to wacika.

Wacika is one of the Hinduism local contents. This method is appropriate for building substantive theory that accommodates material and non-material aspects. Therefore, wacika approach requires data derived from interactions. The interaction consists of interviews, observations, and researcher's experience. The researcher interviewed eight people relevant with the objective of this study. The discussions during the interviews encouraged the informants to share information or their perspectives to confirm and obtain significant local and specific information. The researcher also observed the cooperatives site. The observations were made to obtain an overview about the real conditions of the cooperatives and to confirm data obtained from other sources. They were conducted in three cooperatives that applied wacika in its SMA operations. The cooperatives are the unit of analysis in this study. 
The researcher positioned herself as the subject and object, acting simultaneously as the research instrument (auto-observation) and as part of it (theoretical attitude), so it can be used to gain a deeper understanding (Denzin \& Lincoln, 2009). This positioning was made because the researcher was an SMA practitioner as well as a supervisor in one of the three cooperatives. In this part, the researcher acted as a naturalistic observer (complete participant). The researcher also made observations at two other similar cooperatives in the province where Hinduism is the major believe, in which the researcher served as a non-participant observer. Thus, the researcher was aware about the real conditions. The cooperatives are the data sources, and the data were used as a basis to generate a substantive theory.

A theory reflects a meaning related to the social interaction (Llewelyn, 2003) that is formed by physical and non-physical aspects (Belkaoui, 2006). It is in accordance with Hinduism, a believe that maintains the balance between material (sekala) and nonmaterial (niskala) aspects. Thus, the researcher could see social interactions which include values in material and non-material balance in religious dimension. This social interactions formed a concept serving as the basis of a theory (Belkaoui, 2006). The acquired preliminary data were analyzed and confirmed to the informants at the observation site in order to obtain relevant data. The data were extracted into a concept. The concept is obtained through the conceptualization process. The process of conceptualization consists of conceptual labels, sub-concepts, and concepts.

The data analysis started from the process of conceptualization. The data from the interaction of data sources was analyzed through comparative analysis of interactions from the sources to find similar conditions. Based on the comparative analyses, the data were identified in the form of conceptualization process, started from conceptual labeling. This procedure was carried out by continuously comparing the relevance of the data through comparative analysis (Creswell, 2015) by segmenting them into conceptual labels until they reached saturation point. The conceptual labels were next segmented into sub-concepts and concepts. The comparative analysis helps find the concept, which was further simplified by reducing the data so that it became more concise and compact. The result was grouped according to relevance into sub-concepts and concepts. The concepts were named through the abstraction process based on certain characteristics for similar data.

After the concepts were found during conceptualization stage, data assessment against concepts was performed. The concepts were tested by asking questions related to the concepts, continued with finding evidence in the data sources (Creswell, 2015). The theory developed in the process of conceptualization stage was validated by comparing the process with the literature (Creswell, 2015), including the values of wacika in Hinduism scripture and accountability reports of supervisory board and management. During the study, additional data were collected by returning to the field until the concepts were saturated and a theory could be developed (Creswell, 2015; Kamayanti, 2016). This stage of saturation showed that no more relevant new concepts can be added.

In the process of conceptualization, the researcher classified the data into conceptual labels that link to wacika category. This aims to form a SMA reference in the form of a conceptual framework built from concepts formation. The concepts formation 
is based on Creswell (2015), in that the categories were described in more detail in subcategories. Based on that the researcher connoted categories as concepts and subcategories as sub-concepts. The sub-concepts were formed by conceptual labels.

Conceptual labels were formed by reducing or merging the data. The abstracted conceptual labels were the sub-concepts that finally generated concepts. These concepts map the patterns of the relationships between concepts in a scheme consisting of model and storyline. The framework model simplified the relationships among concepts. The relationships among concepts were formed by making a storyline (Creswell, 2015). The storyline supporting the model contained a linkage of concepts that describes a substantive theory in the form of wacika-based conceptual framework.

The concepts were linked by integrating them into a conceptual framework that constituted the finding of present study. The have implications for the development of theory (Creswell, 2015 849-868) built with synergy concepts as the pillars. Synergizing the concepts makes the relationships among concepts generated by sub-concepts in the form of abstract description of relationships among concepts to produce a theory (Creswell, 2015).

This conceptual framework will be more effective if the SMA practitioner of the cooperatives are committed to internalize and integrate wacika values of dharma into the organizations. The essence of this merging process was the researcher's theoretical sensitivity to find the theorization of all concepts. Theoretical sensitivity was built through interpretation and reflection on the data sources and the understanding of basic concepts related to the research objectives.

\section{RESULTS}

Wacika concepts in SMA should be controlled by communicating information that provides sekala (material) and niskala (non-material) benefits for the management. Wacika concepts in SMA includes six concepts constituted from eight sub-concepts, which were formed from 14 conceptual labels. The followings are the concepts that contain wacika concepts in SMA.

The first concept is that wacika outlines the information being communicated by considering love, truth, kindness, and commitment through positive, useful, and valueadded information. The first concept consists of one sub-concept that describes the concept. The sub-concept is formed from a conceptual label that wacika reminds people to avoid evil words, violent words, defamation, and lie (untrustworthy). It means wacika in SMA encourages a healthy and productive communication and builds awareness and commitment to providing relevant, necessary, and accountable information. It forms the management's understanding of how the cooperatives can give material and nonmaterial benefits. Thus, SMA information contains enlightened knowledge towards a balanced welfare. This is shown by the fact that all elements of the cooperatives play an active role by not informing things that have moral hazard impacts.

The second concept is education, communication, and information literacy based on wacika. The second concept is made from the sub-concept of communication and education of contributions, rights, and obligations. This sub-concept is constructed from three conceptual labels: education with regard to understanding of cooperatives, 
education to increase contribution to cooperatives, and education of rights and obligations. Wacika in SMA encourages the management's understanding of the cooperative and its management. This understanding of the cooperative constitutes the strength of SMA information system. Education supports this understanding. Educational programs are conducted to improve the understanding and business enlightenment according dharma. Education is conducted for prospective members, members, employees, SMA practitioners, and the management. This education encourages the human resources of the cooperatives to actively carry out their functions and roles. This awareness and commitment form a productive cooperative and become a business sustainability capital. It is communicated for mutual understanding. Communications programs are conducted routinely through information sharing that encourages all elements to provide input for the improvement of the cooperatives. It leads to the commitment to implement the decision together. SMA information needs to be conveyed to energize the positive participation to produce reliable and necessary SMA information. This literacy program encourages SMA practitioners to determine when information is needed, collected, evaluated or analyzed, and recommended timely and appropriately to the management. Thus, SMA practitioners must have the skill to literate the information.

The third concept is deliberation. This concept is made from the sub-concept of democratic and coordinated management. This sub-concept is segmented from two conceptual labels. They are democratic and coordinated management in accordance with provisions and deliberation for the common good. The cooperatives have the characteristics of prioritizing mutual interests that motivate all elements of the cooperative to provide constructive advice and information. This indicates that cooperatives are managed democratically by prioritizing deliberation. Deliberation is conducted with regard to evaluation efforts, risk management, and performance management and is supported by strategic improvement and action recommendation.

The fourth concept is transparency that is composed from three sub-concepts; they are welfare-making transparency, vocal point optimization for local champion, and sharing. The concept of welfare-making transparency is segmented from ethics-bound transparency and information disclosure. Transparency is achieved by creating reliable reports. This transparency should be supported by an accountable information disclosure with regard to the ethical values, control systems, and information systems. Transparency is related to vocal points, which are developed in a healthy, harmonious, and solid coordination. This transparency builds the vocal points cultural awareness, respect for other opinions, and information sharing in generating local champions (productive information that leverages existing potential). Vocal points need the involvement of cooperative elements in decision making that leads to the commitment to advance the cooperative. The concept of vocal point optimization for local champion is formed from the conceptual label consisting of optimizing local champion with the support of the management contribution and active participation of members. Vocal point awareness and commitment produce local champions. The sub-concept of sharing is formed from the conceptual labels of sharing with sincere intention and motivating to share insight. Information is obtained through both vocal point and identification from SMA practitioners, and it was collected according to management's needs. Thus, SMA 
information encourages transparency for a sound management of the cooperative and mutual-trust building. The transparency shows the form of accountability with the intention of encouraging suggestions, cross-checking and balancing, and executing the system.

The fifth concept is integrity, which is formed from the sub-concept of positive commitment. The sub-concept is segmented from the conceptual labels of being honest, accountable, trustworthy, and responsible. The integrity encourages work professionalism that affects the system and constitutes a strong characteristic in developing a solid cooperative.

The sixth concept is learning, which is built from the sub-concepts of evaluation and corrective action. The sub-concepts are segmented from three conceptual labels consisting of information from various parties relating to mutual decisions, intensive communication, and members being able to provide input for correction. Learning is carried out with the awareness that evaluation is an effort for improvement for mutual good and welfare. Thus, learning encourages the spirit of evaluation, innovation, creativity, and performance improvement. The value of learning is embedded in the system or rules, and awareness and joint commitment are followed by corrective action.

Based on the six concepts from the process of conceptualization, the concepts were integrated and harmonized to produce a substantive theory of SMA conceptual framework model based on wacika. The concepts are the basis bridging SMA purposes to local content. It indicates that SMA is implemented in wacika values (local content). It means that the conceptual framework stimulates SMA practitioners to perform their function and role with the motivation to produce necessary and reliable SMA information according to the dharma. Wacika constitutes the core of SMA implementation to achieve the synergy of the purposes. This indicates that wacika in SMA controls the words in ethics and morals. It also stimulates the capability of affecting the cooperatives' decision-making management .

The six concepts were interrelated based on the synergy of life balance between local content and the nature of SMA itself. The synergy among the concepts helps the researcher link concepts which were then used to build an SMA conceptual framework in Hindu cooperatives. The six concepts of wacika values derived from the process of conceptualization are grouped in the scheme of wacika values that maps the relationships among concepts and describes how SMA works to affect management's decision.

\section{DISCUSSIONS}

Wacika in SMA plays a role in building useful, harmonious, and healthy interactions that promote a conducive working atmosphere. These interactions build mutual respect and willingness to learn for mutual improvement. It is achieved by involving participation and joint commitment through vocal points to produce local champions. This condition is related to the establishment of individual's and cooperative community's integrity. It leads to a healthy and solid interaction that forms a system and values based on wacika as a part of dharma.

The six wacika concepts are consolidated into two nodes of wacika in SMA. The first node is democratically managed management, and the solid coordination within 
wacika values plays a role in building transparency and communication that produce local champions. The second node is management that prioritizes literacy skill with integrity supported by sekala and niskala education and learning for building useful information.

The six concepts of wacika constitute the pillars of an SMA conceptual framework in cooperatives oriented to practicing dharma values. This conceptual framework consists of three levels referring to the level of Hinduism framework basis, which apparently is the nature of knowledge to achieve the balance of life.

The first level represents tattwa (philosophy) in Hinduism framework basis. The first level of SMA conceptual framework is purpose, where wacika underlies information that provides material and non-material utility (the first concept). The second level represents susila (ethics) in Hinduism framework basis. The second level of SMA conceptual framework consists of assumptions and principles, which serve as a code of conduct, a social rule of interaction that must be obeyed and is bound by social sanctions. The assumptions became references based on data or facts in a substantive locality environment.

The first assumption is education, communication, and information literacy based on wacika. These are in accordance with the principle of cooperatives in Indonesia pursuant to Law No. 25 of 1992 RI, namely cooperative education. Prior to becoming members, prospective members need to be provided with understanding of product knowledge and awareness to become an active member. In addition to providing product knowledge education, it is also necessary for educating them on how to manage the cooperative, preparing them to succeed the management, and preparing them to carry out their function whenever the members elected them as managers and supervisors.

The second assumption is learning, which is closely related to the transfer of knowledge for the formation of attitudes and trust in the cooperatives. SMA practitioner learning was carried out continuously through information sharing, evaluation, solution seeking, training, and follow-up action. Both assumptions are related to principles.

The principles constitute the basis for the development of SMA techniques, strategies, and information. The principles of cooperatives within the SMA conceptual framework in these cooperatives are the integration of cooperative's principles according to the prevailing laws and the principles of SMA values. The principles of SMA conceptual framework in cooperatives with Hindu missions are deliberation and integrity. Deliberation is conducted through evaluation, discussion, and solution recommendation through strategy in order to reach a consensus. This illustrates that cooperatives have family ties that help each other among stakeholders. Integrity provides a sturdy human capital in the implementation of principle limited by dharma (virtue and truth in Hinduism) and karmaphala (a believe that all actions have implications for the outcome of action that is inseparable from God's role). Integrity is shaped and formed by the interaction of awareness of the internalization of dharma values to form a reasonable SMA.

The third level represents upacara (the best work with sincere intentions is like being offered to God) in Hinduism framework basis. The third level of SMA conceptual framework is the characteristic of SMA information, i.e. transparency. It upholds 
information that is fairness and as is, responsibility, and fairness as a form of responsibility. Information transparency will lead to a sense of belonging, capable of stimulating SMA practitioners and management to contribute their best to the cooperative. Thus, transparency guides SMA in balancing between material and nonmaterial aspects complying to Hinduism through wacika.

\section{Conclusions}

Wacika -based SMA conceptual framework is a reference for SMA practitioners to improve their roles and functions in cooperatives practicing dharma values. This conceptual framework is built on the six pillars of wacika-based SMA concept, which is divided into three levels according to the three bases of Hindu framework. It is because the wacika-based SMA conceptual framework is based on basic Hindu frameworks. The first level represents the philosophy of life, the second level represents ethics and governance, and the third level represents the implementation. Wacika within SMA conceptual framework constitutes a control system and forms the characteristics of SMA practitioners in order to be able to provide information, communicate, and literate productive information that is materially and non-materially useful. With this framework, SMA practitioners are motivated to have a sensitivity and ability to literate financial and non-financial conditions and forward them to the management through vocal points to produce local champions.

SMA conceptual framework is as a reference to develop SMA. It is a reference for SMA practitioners to identify, analyze, and recommend reliable and valuable SMA information. Wacika- based SMA conceptual framework information is greatly useful for evaluation, learning, and performance improvement. This means that SMA information does not only deal with the provision of information for decision-making consideration but also deals with enlightenment of knowledge and benefits for cooperatives through the synergy of purposes to achieve improved welfare.

Wacika-based SMA conceptual framework is internalized in SMA activities. The internalization of wacika-based SMA conceptual framework constitutes a form of enhancement of business-oriented awareness according to dharma. This conceptual framework needs to be integrated into the cooperative's management system as part of the decision-making process. Wacika in SMA stimulates an active participation in a solid team coordination for creativity and useful innovation. This demonstrates that wacika-based SMA conceptual framework implements dharma by driving motivation to develop creative solutions, forming a commitment to develop insights, and building information sharing cooperation to produce reliable and relevant information for the management. Thus, SMA conceptual framework controls ethical and moral awareness, disseminates virtues, drives learning, and provides motivation to carry out functions that provide benefits according dharma. 


\section{REFERENCES}

Ahmad, K. (2012). The Use of Management Accounting Practices in Malaysian SMEs. University of Exeter as Thesis for the degree of Doctor of Philosophy in Accountancy. Alleyne, Marshall, D. (2011). An Exploratory Study of Management Accounting Practices in Manufacturing Companies in Barbados. International Journal of Business and Social Science, 2(10), 61-70.

Al-Mawali, H., \& Amoush, A. (2013). Customer Accounting Information Usage: A Mixedmethod Study. Interdisciplinary Journal of Contemporary Research in Business, 5(6), 392-403.

Apak, S., Erol, M., Elagöz, ì., \& Atmaca, M. (2012). The Use of Contemporary Developments in Cost Accounting in Strategic Cost Management. Procedia-Social and Behavioral Sciences, 41, 528-534. http://doi.org/10.1016/j.sbspro.2012.04.065

Aziz, A. M. (2012). Strategic Role of Strategic Management Accounting Towards Enhancing SMEs Performance in Iraq. Thesis Submitted to the Othman Yeop Abdullah Graduate School of Business, University Utara Malaysia, in Fulfillment of the Requirement for the Masters Degree of International Accounting, 1-74. Retrieved from http://etd.uum.edu.my/3197/2/AZIZ_MOHAMMED_AZIZ.pdf

Belkaoui, A. R. (2002). Behavioral Management Accounting. London: Quorum Books.

Belkaoui, A. R. (2006). Teori Akuntansi. (Krista, Ed.) (Edisi 5, B). Jakarta: Salemba Empat. Brouthers, K. D., \& Roozen, F. A. (1999). Is It Time to Start Thinking About Strategic Accounting ? Elsevier Science Ltd, 32(3), 311-322.

Coad, A. F. (1996). Smart work and hard work: explicating a learning orientation in strategic management accounting. Management Accounting Research, (April), 387-408.

Coad, A. F. (1999). Some survey evidence on the learning and performance orientations of management accountants. Management Accounting Research, (June 1997), 109-135.

Corbin, J., \& Strauss, A. (1990). Grounded Theory Research: Procedures, Canoan and Evaluative Criteria. Qualitative Sociology, 13(1), 418-427 (3-21). http://doi.org/10.1007/BF00988593

Creswell, J. W. (2015). Penelitian Kualitatif \& Desain Riset: Memilih di antara Lima Pendekatan. (S. Z. Qudsy, Ed.) (Edisi ke-3). Yogyakarta: Pustaka Pelajar translated by SAGE.

Denzin, N. K., \& Lincoln, Y. S. (2009). Handbook of Qualitative Research: Metodologi Grounded Theory Ulasan Singkat Anselm Strauss \& Juliet Corbin. Yogyakarta: Pustaka Pelajar translated by Sage Publication Pvt. Ltd. http://doi.org/10.1111/j.1365-2648.2005.03538_2.x

Dixon, R. (1998). Accounting for Strategic Management : A Practical Application. Elsevier Science - Long Range Planning, 31(2), 272-279.

Dunkovic, D., Juric, D., \& Nikolic, T. (2010). Marketing Aspects in Strategic Management Accounting. Interdisciplinary Management Research, 6, 739-750.

Engineer, A. A. (2009). Islam dan Teologi Pembebasan. Yogyakarta: Pustaka Pelajar.

Forsaith, D., Tilt, C., \& Xydias-lobo, M. (2004). The Future of Management Accounting a South Australian Perspective. JAMAR, 2(1), 55-69. 
Fowzia, R. (2011). Strategic Management Accounting Techniques : Relationship with Business Strategy and Strategic Effectiveness of Manufacturing Organizations in Bangladesh. World Journal of Management, 3(2), 54-69.

Ho, J. K. (2014). An Exploratory Exercise to Establish the Profile of a Double-hybrid Management Accountant with Justifications. European Academic Research, I(11), 4261-4273.

Hoffjan, A., \& Wompener, A. (2006). Comparative Analysis of Strategic Management Accounting in German - and English - Language General Management Accounting Textbooks. Textbooks SBR, (July), 234-258.

Hoque, Z. (2006). Methodological Issues in Accounting research: Theories and Methods and Issues. Spiramus.

Juras, A. (2014). Strategic Management Accounting - What Is the Current State of the Concept ? Economy Transdisciplinarity Cognition, 17(2), 76-83.

Kamayanti, A. (2016). Metodologi Penelitian: Kualitatif Akuntansi Pengantar Religiositas Keilmuan. Jakarta Selatan: Ngapurancang.

Kieso, D., Weygandt, J., \& Warfield, T. (2011). IFRS Edition: Intermediate Accounting (Volume 1). Hoboken: John Wiley \& Sons.

Kozarkiewicz, A., \& Lada, M. (2014). Strategic Management Accounting as a Source of Information for Value-Driven Project Management. Journal of Economics, Business and Management, 2(3), 186-190. http://doi.org/10.7763/JOEBM.2014.V2.122

Langfield-Smith, K. (2008). Strategic management accounting: how far have we come in 25 years? Accounting, Auditing \& Accountability Journal, 21(2), 204-228. http://doi.org/10.1108/09513570810854400

Llewelyn, S. (2003). What counts as "theory" in qualitative management and accounting research? Introducing five levels of theorizing. Accounting, Auditing \& Accountability Journal, 16(4), 662-708. http://doi.org/10.1108/09513570310492344

Lo, L. (2011). "Strategic" conceptualization in management accounting or SMA. Science Direct.

Lord, B. R. (1996). Strategic management accounting: the emperor's new clothes? Management Accounting Research, 7(April 1994), 347-366. http://doi.org/10.1006/mare.1996.0020

Ma, Y., \& Tayles, M. (2009). On the emergence of strategic management accounting: An institutional perspective. Accounting and Business Research, 39(5), 473-495. http://doi.org/10.1080/00014788.2009.9663379

Mathras, D., Cohen, A. B., Mandel, N., \& Mick, D. G. (2015). The effects of religion on consumer behavior: A conceptual framework and research agenda. Journal of Consumer Psychology, 1-14. http://doi.org/10.1016/j.jcps.2015.08.001

Mckinlay, A., \& Pezet, E. (2010). Critical Perspectives on Accounting Accounting for Foucault. Critical Perspectives on Accounting, 21(6), 484-493. http://doi.org/10.1016/j.cpa.2009.08.006

Molisa, P. (2011). A Spiritual Reflection on Emancipation and Accounting. Critical Perspectives on Accounting, 22(5), 453-484. http://doi.org/10.1016/j.cpa.2011.01.004

Nielsen, L. B., Mitchell, F., \& Nørreklit, H. (2014). Management Accounting and Decision 
Making: Two Case Studies of Outsourcing. Accounting Forum, 1-19. http://doi.org/10.1016/j.accfor.2014.10.005

Nishimura, A. (2005). The Development of Management Accounting and the Asian Position. Workshop Internasional Akuntansi Dan Isu-Isu Keuangan.

Noordin, R., Zainuddin, Y., \& Tayles, M. (2009). Strategic Management Accounting Information Elements : Malaysian Evidence. Asia-Pacific Management Accounting Journal, 4(1), 17-34.

Nyamori, R. (2000). Strategic Accounting Revisiting The Agenda. School of Accountancy, Massey University, Working Pa(August), 1-23.

Orsi, R. A. (2003). Is the Study of Lived Religion Irrelevant to the World We Live in? Special Presidential Plenary Address, Society for the Scientific Study of Religion, Salt Lake City. Journal for the Scientific Study of Religion, 42(2), 169-174. http://doi.org/10.1111/1468-5906.t01-1-00170

Pipan, T., \& Czarniawska, B. (2010). How to construct an actor-network: Management accounting from idea to practice. Critical Perspectives on Accounting, 21(3), 243251. http://doi.org/10.1016/j.cpa.2008.04.001

R. Roslender, S. Hart, J. G. (1998). Strategic management accounting : Refocusing the agenda. Management Accounting Research, 44-46.

Ramljak, B. (2012). Strategic Management Accounting Practices in Croatia. The Journal of International Management Studies, 7(2), 93-100.

Roslender, R., \& Hart, S. J. (2010). Strategic Management Accounting : Lots in a Name? Www.hw.ac.uk, (September), 1-27.

Sarasamuscaya. (n.d.). Hindu scriptures. Retrieved from http://sastrabali.com/sarasamuscaya/

Setiawaty, S. (2012). Mengapa Koperasi Tidak Berkembang dan Maju Secara Signifikan. Universitas Gunadarma.

Shank, J. K. (2006). Strategic cost management : upsizing, downsizing, andright (?) sizing. Contemporary Issues In Management Accounting, (Oxford University Press New York), 355-365.

Šoljaková, L. (2012). Strategic management accounting : why are not expectations fulfil ? In Advances in Finance and Accounting (pp. 217-221).

Sudaryanti, D., Sukoharsono, E. G., Baridwan, Z., \& Mulawarman, A. D. (2015). Critical Analysis on Accounting Information Based On Pancasila Value. Procedia-Social and Behavioral Sciences, 172, 533-539. http://doi.org/10.1016/j.sbspro.2015.01.399

Waweru, N. M. (2010). The origin and evolution of management accounting : a review of the theoretical framework. Problems and Perspectives in Management, 8(3), 165-182.

Zaitul. (1988). Tinjauan kritis tentang pengaruh budaya terhadap sistim akuntansi. $F E$ Universitas Bung Hatta, 1-5. 
